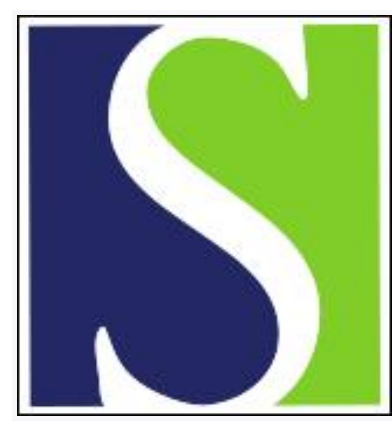

Scand J Work Environ Health 1996;22(1):62-65

https://doi.org/10.5271/sjweh.111

Issue date: Feb 1996

\title{
A fatal case of hard-metal disease
}

by Ruokonen E-L, Linnainmaa M, Seuri M, Juhakoski P, Söderström K-O

The following article refers to this text:

Key terms: alveolitis; cobalt; grinding; hard metal

This article in PubMed: www.ncbi.nlm.nih.gov/pubmed/8685677 


\title{
A fatal case of hard-metal disease
}

\author{
Eeva-Liisa Ruokonen, MD, ${ }^{1}$ Markku Linnainmaa, PhL, ${ }^{2}$ Markku Seuri, MD, ${ }^{2}$ Petri Juhakoski, MD, ${ }^{3}$ \\ Karl-Ove Söderström, $M D^{4}$
}

\begin{abstract}
Ruokonen E-L, Linnainmaa M, Seuri M, Juhakoski P, Söderström K-O. A fatal case of hard-metal disease. Scand J Work Environ Health 1996;22:62-5.

Objectives The purpose of this report is to present a case of hard-metal disease in which the symptoms and findings were minimal early in the disease, but further exposure rapidly led to a fatal outcome.

History A 22-year-old nonsmoking white male, employed for over four years in hard-metal tool grinding, started experiencing a dry cough and shortness of breath during exercise. Preliminary investigations did not reveal any cause for these symptoms, and the patient continued to work. Several months later he developed clinically apparent alveolitis with recurrent pneumothorax. Pulmonary infiltrates in chest radiographs did not disappear during corticosteroid treatment. Soon it was evident that the patient had irreversible pulmonary failure, and a bilateral lung transplantation was performed. No signs of rejection were seen in the resected lungs. The patient died of pneumonia five months later, but no signs of hard-metal disease were found in the transplanted lung.

Conclusions This fatal case of hard-metal lung disease demonstrates that symptoms and findings in pulmonary function tests or chest radiographs may be minimal or misleading in the early stages of the disease. Cobaltexposed workers with inexplicable respiratory symptoms should be closely monitored and the exposure should be suspended.
\end{abstract}

Key terms alveolitis, cobalt, grinding, hard metal.

Pulmonary diseases caused by exposure to hard-metal dust can be classified into two (1) or three groups (2). In cases of pulmonary asthma, cobalt exposure can be followed by immediate, late, or dual asthmatic reactions (3). Sometimes a type I allergic reaction has been assumed to be the cause, and specific immunoglobulin $\mathrm{E}$ (IgE) antibodies against a complex composed of cobalt and albumin have been detected (3). Cases of acute pneumonitis (2), alveolitis (4) or interstitial pneumonia (5) have also been reported. It is not known whether repeated acute phases of the disease are the cause of hard-metal pneumoconiosis or whether the fibrosis, which is rare among hard-metal workers, is a separate disease (2). The finding of giant cell interstitial pneumonia is considered almost pathognomonic of hard-metal disease even though hard-metal pneumoconiosis can also be detected without giant cells being present (5).

The pathogenetic mechanism of pulmonary diseases caused by occupational exposure to hard-metal dust is not clear. Workers are not only exposed to cobalt, but also to several other substances, such as tungsten carbide, titanium carbide, iron, silica, and diamond (6). Hard-metal grinders are also often exposed to coolant mists that can cause asthma (7) or alveolitis (8). The few studies that have been carried out in cobalt refineries, where exposure involves only cobalt, have not found typical cases of interstitial pulmonary disease $(6,9,10)$. Some experimental studies have shown in vivo and in vitro that biological reactivity to a mixture of cobalt and tungsten carbide is much greater than that to cobalt alone $(11-13)$. Even if exposure to airborne cobalt dust is essential in the pathogenesis of hardmetal lung fibrosis, it is not necessarily a sufficient cause (6)

The purpose of this report is to present a case of hardmetal disease in which the symptoms and findings were minimal early in the disease, but further exposure rapidly led to a fatal outcome.

1 Turku University Central Hospital, Department of Pulmonary Diseases, Turku, Finland.

2 Kuopio Regional Institute of Occupational Health, Kuopio, Finland.

3 Pulssi Clinic, Occupational Health Care Department, Turku, Finland.

4 Turku University Central Hospital, Department of Pathology, Turku, Finland.

Reprint requests to: Mr Markku Linnainmaa, Kuopio Regional Institute of Occupational Health, PO Box 93, FIN-70701 Kuopio Finland. 


\section{Case history}

The patient, a Finnish man 22 years of age, had been employed for almost 4.5 years in a company maintaining hard-metal blades. Only two people worked for the company, the patient and the owner. Hard-metal blades were sharpened with two semi-automatic machines for wet grinding and one manually operated machine for both wet and dry grinding. The patient worked with the semiautomatic machines. In addition to grinding the hardmetal tips of the blades, he brazed new tips to the blades for 1 to $2 \mathrm{~h}$ a day.

Over the first four years of employment, including the time when the patient started having symptoms and was first examined, the work was done in an old blacksmith's workshop about $60 \mathrm{~m}^{2}\left(210 \mathrm{~m}^{3}\right)$ in size. The workshop had natural ventilation with one local exhaust hood in the area where hard-metal tips were brazed. No occupational hygiene measurements were made on these premises. However, according to several measurements in similar small workshops, the ambient cobalt concentrations could have exceeded the Finnish occupational exposure limit $\left(0.05 \mathrm{mg} \cdot \mathrm{m}^{-3}\right)(14)$.

Later, the machines were transferred to larger premises $\left(180 \mathrm{~m}^{2}, 630 \mathrm{~m}^{3}\right)$ with mechanical ventilation. The patient worked on these premises for the last five months until April 1991. In this workshop, the air concentrations of cobalt dust were less than one-tenth of the Finnish occupational exposure limit.

In February 1990, after more than four years of grinding tools containing hard metal, the patient started experiencing a dry cough and shortness of breath during exercise. Terbutaline, prescribed by an occupational health physician, produced some relief of the symptoms. The patient's chest radiographs were considered normal at the time, but minor central opacities were noticed when the radiographs were examined later. Because the symptoms continued, the patient was referred to the pulmonary department of the local university hospital.

On examination in October 1990, the patient was slim and asthenic, but his general condition was good. He had no history of atopy and he had never smoked. His heart and breath sounds were normal, and his breathing rate was 35 inhalations per minute. The peak expiratory flow rate (PEFR) was $5251 \cdot \mathrm{min}^{-1}$. Despite repeated attempts to perform a spirometric test, the patient could not make a satisfactory expiration, and thus no spirometric results were available. The resistance of the airways in body plethysmography was $73 \%$, and the specific airway conductance was $141 \%$ of the respective reference value. The total lung capacity (TLC) and other lung volumes were very low because the patient was not able to make a forced expiration.

The patient's condition was not considered to be work-related, and he continued to work. Because the symptoms worsened, he was referred again to the pulmonary department in April 1991. He had lost weight and was short of breath even at rest. His breathing rate was 40 inhalations per minute, his heart rate 100 beats per minute, and his blood pressure $120 / 80 \mathrm{~mm} \mathrm{Hg}$ $(16.0 / 10.7 \mathrm{kPa})$. Neither crepitations nor wheezing could be heard on auscultation. The chest radiographs revealed interstitial and alveolar infiltrates in both lungs, a partial pneumothorax, and pleural fluid posteriorly and posterolaterally on the right side (figure 1). Pleural aspiration yielded a few milliliters of a clear, yellowish fluid with negative bacterial cultures. Two days after the pneumothorax had been successfully treated with suction, the patient complained of sudden and intense chest pain. In the chest radiographs, a tension pneumothorax delocating the mediastinum to the left was seen. This time, the pneumothorax was not completely cured by suction.

The diffusing capacity of the lungs for carbon monoxide $\left(\mathrm{DL}_{\mathrm{CO}}\right)$ was $40 \%$, and the transfer coefficient $\left(\mathrm{DL} \mathrm{CO}_{\mathrm{A}} / \mathrm{V}_{\mathrm{A}}\right) 111 \%$, of the respective reference values. The partial pressure of oxygen in the arterial blood was 12.4 $\mathrm{kPa}$, and that of carbon dioxide was $6.5 \mathrm{kPa}$. The abdominal ultrasonographic recording was normal. Because sarcoidosis or some allergic disease was suspected, oral corticosteroid treatment was started, and it relieved the symptoms somewhat.

No abnormalities were observed in the bronchoscopic examination. A bronchial biopsy showed mild bronchitis. The cells in the bronchoalveolar lavage (BAL) fluid included $13 \%$ eosinophils and some multinucleated giant cells. On thoracoscopy, a lung biopsy was taken

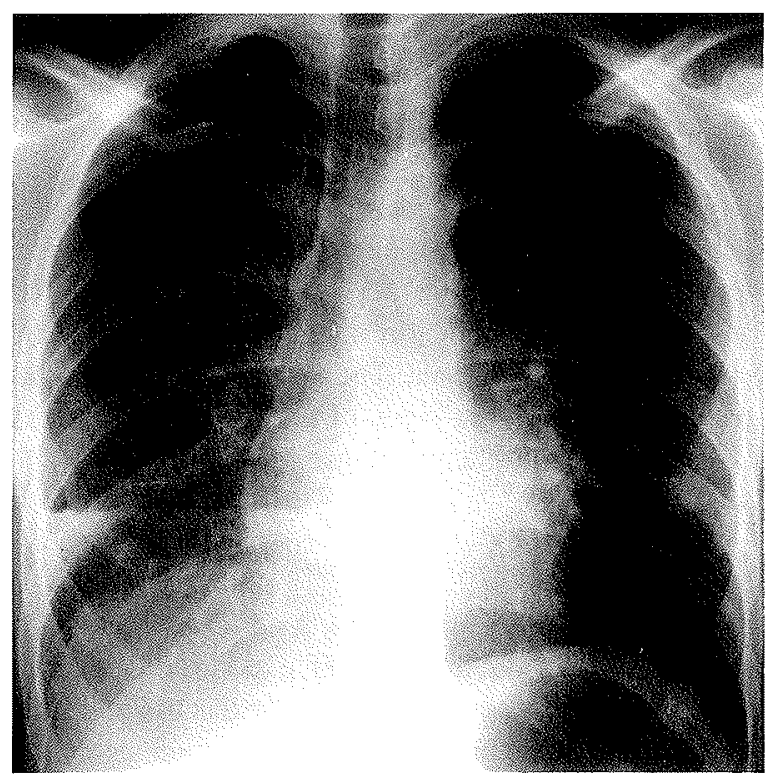

Figure 1. Chest radiograph taken in April 1991 when the patient came to the hospital. Interstitial and alveolar infiltrates in both lungs and a partial pneumothorax are seen on the right side. 


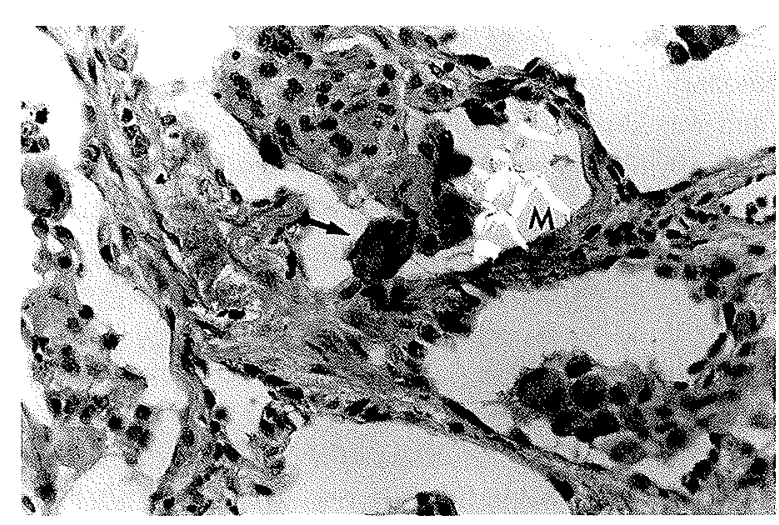

Figure 2. Micrograph of the lung showing somewhat broadened and fibrotic alveolar septa. Some multinucleated giant cells are seen in the septa (arrow). In the alveoli, foreign material (metal particles) can be seen (M). (Hematoxylin-eosin staining, magnification $800 \times$ )

from a nodulus on the surface of the right lower lobe; it revealed allergic or hypersensitivity alveolitis with some multinucleated cells.

Because the infiltrates in the chest radiographs did not disappear during corticosteroid treatment, a thoracotomy with open lung biopsy was performed in May 1991. In the operation, the lung tissue was contracted and did not expand even with high ventilatory pressure. The lung biopsy showed typical findings of hard-metal lung disease with interstitial fibrosis and alveolar infiltration with macrophages and giant cells (figure 2). Carbon and birefringent crystals were found in the macrophages and the fibrotic tissue. In the particle analysis, the total number of particles was about 600 million in one gram of dry lung tissue; this value is about 10 -fold higher than the normal level obtained with the method used. About $75 \%$ of the particles were tungsten carbide, but no cobalt was found. The BAL and the lung biopsy findings indicated an occupational etiology for the disease and the diagnosis of hard-metal disease.

Following the thoracotomy the state of the patient deteriorated. A bilateral lung transplantation was performed in January 1992. The operation itself was successful with no complications, but five months later the patient died of pneumonia. The autopsy revealed pulmonary infection, but no signs of rejection or hard-metal disease in the transplanted lungs.

\section{Discussion}

This patient continued his work with exposure to hardmetal dust for over a year after experiencing his first respiratory symptoms. The occupational cause of his disease was not noted until the lung biopsy findings in May 1991. Afterwards it became clear that the small central pulmonary opacities should not have gone unnoticed in the first chest radiographs in February 1990. The peri- pheral alveolitis type of infiltrates were seen a year later in April 1991. Since the consistency of the lung tissue in the thoracotomic specimen was, according to the performing surgeon, "similar to that of the parenchymal organs," the fibrosis must have progressed. It is possible that the patient had a subacute fibrosis that was complicated by an alveolitis type of acute reaction in April 1991. Multinucleated giant cells and interstitial fibrosis were seen in the histopathological examination. Similar giant cells can be seen in some viral and fungal infections, in tuberculosis, and in foreign body reactions (15), but these diseases were ruled out by other histological, serological, and bacteriological examinations. Ohori et al (5) have indicated that giant cell interstitial pneumonia is almost pathognomonic of hard-metal disease. The lung biopsy specimens of our case included high concentrations of tungsten in the X-ray microanalysis and particle analysis and thus supported the diagnosis of hard-metal disease. The lack of cobalt particles has been attributed to the rapid dissolution and clearance of cobalt from lung tissue (16).

A case of recurrent giant cell pneumonitis in a transplanted lung, in the absence of further hard-metal exposure, has been published (17). Two years after a successful lung transplantation the patient had typical features of giant cell pneumonitis but no evidence of inorganic particles in the transplanted lung. Our patient survived only about five months after the transplantation, and the transplanted lungs had no signs of hard-metal disease at death.

In the preliminary examinations, the patient's poor performance in the lung function tests was considered to be due to his asthenic status and lack of coordination, and his symptoms seemed to be caused by hyperventilation and anxiety. Symptoms of hard-meal disease can vary and are often misleading. Cugell (15) has described the diagnostic procedures in his review. In several cases, the symptoms have been present for years $(2,18-20)$, and many symptomatic treatments have been tried, for example, antibiotics, bronchodilators, and corticosteroids (21). In other cases, such as the present one, the findings are minimal early in the disease, but further exposure leads to a fatal outcome (16). In our case, even though the machinery was transferred to a larger and better ventilated workroom, where the hygienic conditions were satisfactory, the patient's symptoms and state deteriorated. It is evident that a worker's exposure to cobalt should be suspended if there is even a slight suspicion of hardmetal disease (18). Exposure to hard-metal dust should always be as low as possible. Even with cobalt dust concentrations that are lower than $0.05 \mathrm{mg} \cdot \mathrm{m}^{-3}$, grinding machines should be enclosed and equipped with a local exhaust system (22). The fact that cobalt also induces allergic asthma (3) adds importance to the need to control even low exposures. 


\section{Acknowledgments}

This study was financially supported by the Fund of the Finnish Anti-Tuberculosis Association.

The authors also thank Päivikki Susitaival for editing the text and Georgianna Oja for the language revision.

\section{References}

1. Scherrer M, Maillard J-M. Hartmetall-Pneumopathien Schweiz Med Wochenschr 1982;112:198-207.

2. Cugell DW, Morgan WKC, Perkins DG, Rubin A. The respiratory effects of cobalt. Arch Intern Med 1990;150:177-83.

3. Shirakawa T, Kusaka Y, Fujimura N, Goto S, Kato M, Heki S, et al. Occupational asthma from cobalt sensitivity in workers exposed to hard metal dust. Chest 1989;95:29-37.

4. Van Cutsem EJ, Ceuppens JL, Lacquet LM, Demedts M. Combined asthma and alveolitis induced by cobalt in a diamond polisher. Eur J Respir Dis 1987;70:54-61.

5. Ohori NP, Sciurba FC, Owens GR, Hodgson MJ, Yousem SA. Giant-cell interstitial pneumonia and hard-metal pneumoconiosis. Am J Surg Pathol 1989;13:581-7.

6. Swennen B, Buchet J-P, Stánescu D, Lison D, Lauwerys R. Epidemiological survey of workers exposed to cobalt oxides, cobalt salts, and cobalt metal. Br J Ind Med 1993;50:835-42.

7. Hendy MS, Beattie BE, Burge PS. Occupational asthma due to an emulsified oil mist. Br J Ind Med 1985;42:51-4.

8. Friend JAR, Gaddie J, Palmer KNV, Pickering CAC, Pepys J. Extrinsic allergic alveolitis and contaminated cooling-water in a factory machine. Lancet 1977;1:297 - 300.

9. Roto P. Asthma, symptoms of chronic bronchitis and ventilatory capacity among cobalt and zinc production workers. Scand J Work Environ Health 1980;6 suppl 1:1-49.

10. Morgan LG. A study into the health and mortality of men exposed to cobalt and oxides. J Soc Occup Med 1983;33: $181-6$.

11. Lison D, Lauwerys R. Biological responses of isolated macrophages to cobalt metal and tungsten carbide-cobalt powders. Pharmacol Toxicol 1991;69:282 -5.
12. Lison D, Lauwerys R. Study of the mechanism responsible for the elective toxicity of tungsten carbide-cobalt powder toward macrophages. Toxicol Lett 1992;60:203-10.

13. Lasfargues G, Lison D, Maldague P, Lauwerys R. Comparative study of the acute lung toxicity of pure cobalt powder and cobalt-tungsten carbide mixture in rat. Toxicol Appl Pharmacol 1992;112:41-50.

14. Linnainmaa M, Kangas J, Kalliokoski P. Exposure to airborne metals in the manufacture and maintenance of hard-metal and stellite blades. Am Ind Hyg Assoc J. In press.

15. Cugell DW. The hard metal diseases. Clin Chest Med 1992;13:269-79.

16. Nemery B, Nagels J, Verbeken E, Dinsdale D, Demedts M. Rapidly fatal progression of cobalt lung in a diamond polisher. Am Rev Respir Dis 1990;141:1373-8.

17. Frost AE, Keller CA, Brown RW, Noon GP, Short HD, Abraham JL, et al. Giant cell interstitial pneumonitis: disease recurrence in the transplanted lung. Am Rev Respir Dis 1993; $148: 1401-4$

18. Konietzko H, Fleischmann R, Reill G, Reinhard U. Lungenfibrosen bei der Bearbeitung von Hartmetallen. Dtsch Med Wohenschr 1980;105:120-3.

19. Tabatowski K, Roggli VL, Fulkerson WJ, Langley RL, Benning T, Johnston WW. Giant cell interstitial pneumonia in a hard-metal worker: cytologic, histologic and analytical electron microscopic investigation. Acta Cytol 1988;32:240-6.

20. Figueroa S, Gerstenhaber B, Welch L, Klimstra D, Smith GJW, Beckett W. Hard metal interstitial pulmonary disease associated with a form of welding in a metal parts coating plant. Am J Ind Med 1992;21:363—73.

21. Rolfe MW, Paine R, Davenport RB, Strieter RM. Hard metal pneumoconiosis and the association of tumor necrosis factoralpha. Am Rev Respir Dis 1992;146:1600-2.

22. Linnainmaa $\mathrm{M}$. Control of exposure to cobalt during grinding of hard metal blades. Appl Occup Environ Hyg. 1995;10: 692-7.

Received for publication: 12 July 1995 